\title{
溶融亜鉛による鋼の液体金属ぜい化割れの 応力集中部に対する影響*
}

\author{
菊 池 昌 利**家沢徹***
}

\section{Effect of Stress-Concentration on Liquid Metal Embrittlement Cracking of Steel by Molten Zinc}

by

\author{
Masatoshi KIKUCHI \\ (Technical Development Bureau, Tomoegumi Iron Works, Ltd., Tokyo) \\ and Tohru IEzAWA \\ (Welding Research Department, Tomoegumi R \& D, Ltd., Tokyo)
}

Tensile tests were carried out in molten zinc by using both welded and machined specimens with a modified reinforcement in order to investigate the factors which influence the "Liquid Metal Embrittlement" (LME) crack initiation of steel by molten zinc, and the relations between the stressconcentration factor $\left(K_{t}\right)$ and the nominal tensile stress levels $\left(\sigma_{c}\right)$, at which the LME cracking initiates, were examined.

The steel pipe welded with several pieces of steel plates was dipped into the molten zinc and its thermal stress distribution was analysed by using the FEM. It was shown that the thermal stresses produced increased as the dipping speed decreased.

By using the results of the FEM analysis, the dipping speed at which a crack would occur at the toe of the welded bead was decided, and the dipping experiment was carried out at this speed. The main results obtained are as follows:

(1) The stress-concentration resulting from the shape of specimens was more influential than the metallurgical effect for the crack initiation of welded joints in molten zinc.

(2) The thermal stress occurred when the steel structural members were dipped into molten zinc, and it increased as the dipping speed decreased. Thus, the increase in dipping speed was effective to prevent crack initiation. キー・ワード：破壊，液体金属ぜい化，溶接，応力集中，溶融亜鉛めっき

(Received June 3, 1981)

\section{1 緒言}

鋼の溶接継手部は母材に比べ溶融覀鉛による液体金 属ぜい化の影響が顕著にあらわれるため，報告されて いるき裂発生事例も溶接部に多い. 溶融亜鉛中におけ る溶接部の性能については先に報告したが, 溶接継手 部にき裂が発生する原因については，まだ研究されて いない，そこでこれを明らかにするために，まず溶接 継手試験片と機械加工による模擬余盛付試験片とを用 い，溶融亚鉛中で引張試験を行い，応力集中部の応力 集中係数 $K_{t}$ と応力・変位曲線, 括よびき裂発生時の 応力 $\sigma_{c}$ との関係を求めることにした.

つぎに，鋼管溶接構造試験体を亜鉛めっきするため

* 原稿受理 昭和56年 6 月 3 日

** 正 会 員 (株)巴組鉄工所技術開発本部 東京都江東区賈洲

*** (株)巴組技研溶接研究部 東京都江東区豊洲
に溶融亜鉛へ浸せきするときに発生する熱応力分布の 時間的変化を有限要素解析によって求める. また, 解 析により熱応力に対する浸せき速度の影響を調べ，こ の結果を確認するための鋼管溶接構造試験体の浸せき 実験に際し，カプセル型高温ゲージによる熱応力測定 を行らことにした．試験体については，あらかじめ溶 接継手部に打ける $K_{t}$ を求めて扣き，有限要素解析に より，浸せき速度との関係に特いてき裂発生条件を求 める.そこで，この浸せき速度で試験体を亜鉛中へ浸 せきし，き裂が発生するかぞらかを調べる．これらの 結果から，従来解決されていなかった溶融亜鉛めっき 時に括ける鋼製品の液体金属ぜい化割れを防止する手 段を見いだそうとするものである.

\section{$2 \cdot 1$ 引張試験}


Table I. Chemical composition of material used.

\begin{tabular}{c|c|c|c|c}
\hline $\mathrm{C}$ & $\mathrm{Si}$ & $\mathrm{Mn}$ & $\mathrm{P}$ & $\mathrm{S}$ \\
\hline 0.16 & 0.34 & 1.38 & 0.020 & 0.014 \\
\hline
\end{tabular}

Table II. Mechanical properties of material used.

\begin{tabular}{c|c|c}
\hline $\begin{array}{c}\text { Yield point } \\
\sigma_{S}\left(\mathrm{kgf} / \mathrm{mm}^{2}\right)\end{array}$ & $\begin{array}{c}\text { Tensile strength } \\
\sigma_{\boldsymbol{B}}\left(\mathrm{kgf} / \mathrm{mm}^{2}\right)\end{array}$ & $\begin{array}{c}\text { Elongation } \\
\boldsymbol{\phi}(\%)\end{array}$ \\
\hline 36 & 56 & 30 \\
\hline
\end{tabular}

実験に供したのは市眅の SM $50 \mathrm{~A}$ 鋼で西り，その 化学成分と機械的性質を Table I, II 飞示す.この材 料を用いて Fig. 1 亿示す引張試験片を製作した。試 験片の長さ方向をロール方向に一致させて採取した. Fig. 1 の(a)，(b)は機械加工による模擬余盛付試験片で, フィレットの肩の角 $\theta$ とノッチ底の曲率半径 $\rho$ を变化 させたものであり, この他に平滑試験片も準備した。 (c), (d)は溶接継手部を有する引張試験片で, 継手形状 は(c)の突合せ溶接継手之(d)の十字すみ肉溶接継手の 2 種類であり, 溶接には JIS D 5016 低水素系溶接棒 L-55, JIS D 5000 特殊系溶接棒M50Gによる手溶接, および YM-26，１.6 ワイヤによる炭酸ガス半自動 溶接を使用した。これらの試験片を特製の引張試験装 置に取付けて, $450^{\circ} \mathrm{C}$ の溶融亜鉛へ浸せきし, 昇温が 完了する 2 分後に負荷を開始して引張試験を行った. そのときの引張速度は約 $10 \mathrm{~mm} / \mathrm{min}$ であった。高温 飞和ける SM $50 \mathrm{~A}$ 鋼の模擬余盛付試験片と溶接継手

(a)

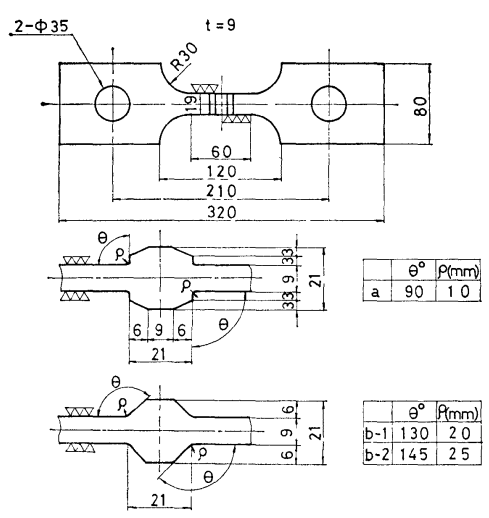

(c)

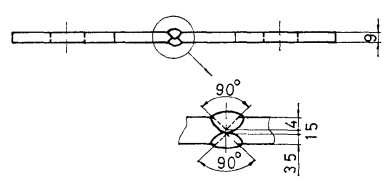

(d)

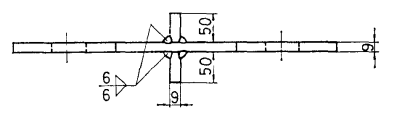

(a), (b); Machined specimen.

(c), (d); Welded specimen.

Fig. 1. Shape and dimension of machined and welded tensile test specimens.
試験片の引張特性を調ベるために，試験片にシリコン ラバーを約 $5 \mathrm{~mm}$ の厚さに被覆し, 溶融巠鉛中に浸せ きして10分後に引張試験を行った。また，亜鉛中での 引張試験に和いて, き裂が発生するときの引張応力を 求めるために，すでに報告したように同一形状寸法の 試験片10本を用い，種々の荷重レベルから除荷したそ れぞれの試験片に対して，き裂の有無を検査して求め るいわゆる除荷法により行った.

\section{$2 \cdot 2$ フィレットの肩の $\theta$ およびノッチ底の曲率半 径 $\rho$ の測定}

溶接ビードトウ部および模擬余盛部の応力集中係数 $K_{t}$ を求めるために, Fig. 2 に示すような形状に対し て板厚 $B$, フィレットの肩の高さ $h$, フィレットの肩 の角 $\theta$, 拉よび,ッチ底の曲率半径 $\rho$ が必要である.

この $\theta, \rho$ を求めるために, 溶接継手引張試験片之鋼 管溶接構造物の溶接ビードトウ部拉よび模擬余盛付引 張試験片の切欠き部について, シリコンラバーを流し 込んで型をとり，シリコンラバーの型をスライスし， その断面形状を万能投影機で10倍に拡大し, トレーシ ングペーパに写し取って $\theta$ とのを測定した. 溶接ビー ドまたは模擬余盛の長さ $19 \sim 34 \mathrm{~mm}$ に対して 3 籄所 測った.

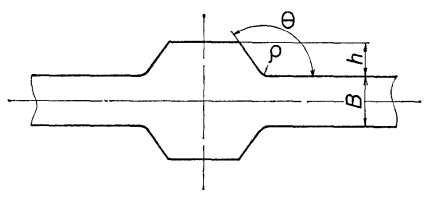

Fig. 2. Shape of the stress-concentrating part.

\section{$2 \cdot 3$ 銅管溶接構造試験体の浸せき実験}

鋼管（STK 55，\$609.6×16 長さ $6000 \mathrm{~mm}$ ) の中 間部飞鋼板 (SM $50 \mathrm{~A}$, 板厚 $16 \mathrm{~mm}$ )を鋼管内を貫通 して十字形に溶接した Fig. 3 亿示す試験体を製作し た. 溶接方法は炭酸ガス半自動溶接で, YM-26, ф 1.6 の溶接ワイヤを用いた．また熱応力の変化を確認 するために，鋼管と鋼板との接合部付近に図の上うに 3 軸方向に 2 籄所カプセル型高温ゲージを溶接し, シ

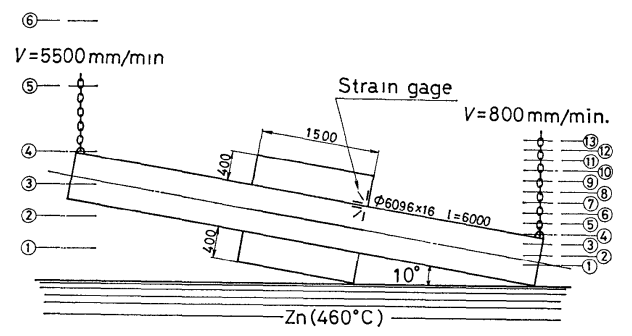

Fig. 3. Schematic illustration of dipping of the steel pipe welded with steel plates into molten zinc. 
リコンラバー，テフロンテープ，物よびステンレス板 で被覆した。これは，試験体とゲージの温度差を少く するためである。試験体は亜鉛液面に対して $10^{\circ}$ 傾斜 させ，鋼管の両端部に取付けた金具をチェーンでっり， $460^{\circ} \mathrm{C}$ の溶融亜鉛中へ $V=800 \mathrm{~mm} / \mathrm{min}$ の速度で浸せ きした。矢のとき同時にひずみ測定を行った。試験体 が完全に浸せきして 5 分後に試験体の温度はほぼ一定 となり熱応力も減衰するので, その時点で亜鉛浴より 引上げた。めっきが完了した後約 $60^{\circ} \mathrm{C}$ 温水中に沈め て冷却後、ひずみゲージ溶接箇所を $120 \mathrm{~mm}$ 角に切出 し，溶融亚鉛に浸せきして動的みかけのひずみる測定 しひずみの補正を行った。すた，鋼管と鋼板の溶接 端部を切出し，10\%硫酸に浸せさして亜鉛を溶解し， き裂の有無を確認した。

\section{3 実験結果および考察}

\section{$3 \cdot 1$ 引張試験験果}

溶融亜鉛中における引張試験結果を応力集中係数 $K_{t} \sum_{88}$ 関係に拈いて調べた. ここで， $K_{t}$ は西田の(1)， (2)式より求めた。

$$
\begin{aligned}
& K_{t}=+\frac{1-\exp \{-0.90 \sqrt{(B+2 h) / 2 h}(\pi-\theta)\}}{1-\exp \{-0.45 \pi \sqrt{(B+2 h) / 2 h}\}} \\
& \times\left(\alpha_{1}-1\right) \\
& \alpha_{1}=1+\left\{\frac{1}{2.8(2 h+B) / B-2} \times \frac{h}{\rho}\right\}^{0.65}
\end{aligned}
$$

$K_{t}=2.0$ の模擬余盛付 試験片による引張試験結果 孝 Fig. 4 に示す。室温と高温空気中での伸びはほぼ

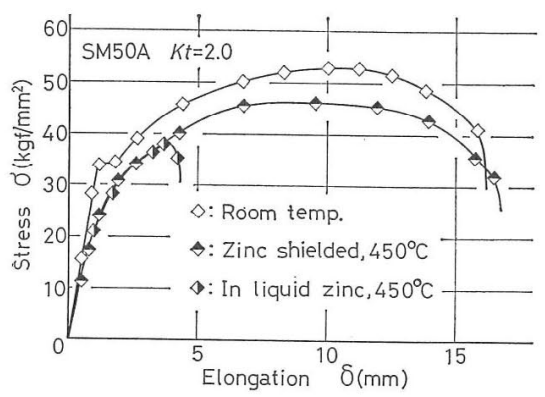

Fig. 4. Stress-elongation curves of tensile tests of the welded bead-shape, machined specimens. The stress-concentration factor $\left(K_{t}\right)$ : 2. 0 .

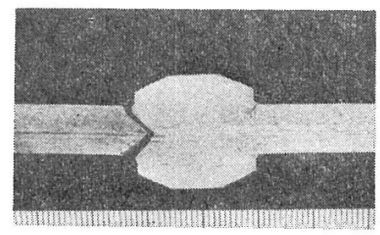

Fig. 5. Photograph of the tensile testing specimen in molten zinc, which was machined into the same shape as the welded bead specimen.
等しいが溶融亜鉛中では同温空気中に比べ，応力，変 位とも低い位置で破断している. $K_{t}=1.0$ の平滑材の 場合に比べて $K_{t}=2.0$ では, 空氮中室温和よび $450^{\circ} \mathrm{C}$ い-゙れも破断時の变位は81\%に減少し，亜鉛中では65 \%に減少して拉り，応力集中の影響が大きく范られ た. $K_{\iota}=2.0$ の模擬余盛付試験片の亜鉛中での引張破 断写真を Fig. 5 に示すが，き裂は応力集中部から発 生し, 斜め方向に進展して破断している.き裂は 4 箇 所すべての切欠き部から発生している。香た，同一試 験片に刘する室温おるび $450{ }^{\circ} \mathrm{C}$ 空気中での破断位置は すべて模擬余盛以外の箇所であった．亜鉛中では液体 金属ぜい化が，特に引張応力の高い応力集中部に顕著 にあらわれる. 模擬余盛付試験片による溶融里鉛中で の引張試験結果を Fig. 6 飞示与。 $K_{t}=1.0$ は平滑材 であり， $K_{t}$ が大きくなるに従い，破断時の変位が減 少している。突合せ溶接継手による引張試験結果を Fig.7 に示す。 ばらつきはあるが，模擬余盛付試験片 の場合と同様な結果が得られ，いずれも形状による影 響が大きいことがわかる。

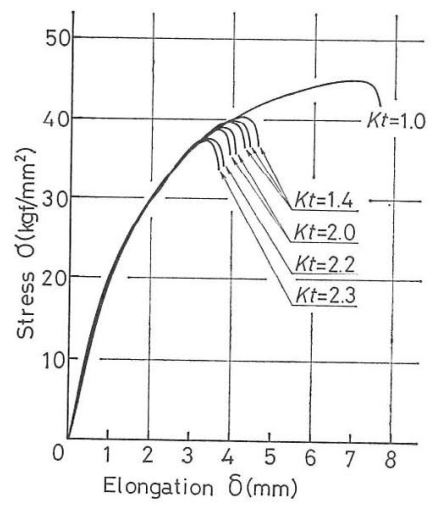

Fig. 6. Effect of stress-concentration factor $\left(K_{t}\right)$ of machined specimens on stress-elongation curves in molten zinc.

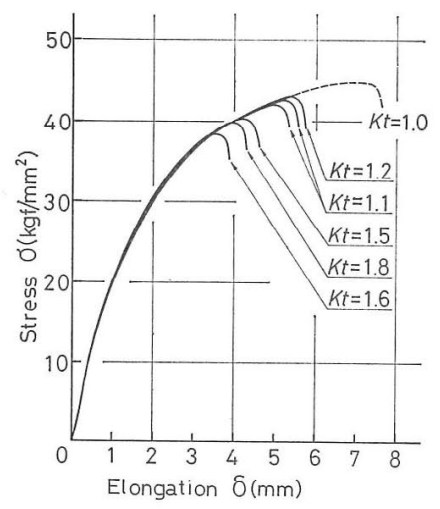

Fig. 7. Effect of stress-concentration factor $\left(K_{\imath}\right)$ of welded specimens on stress-elongation curves in molten zinc. 


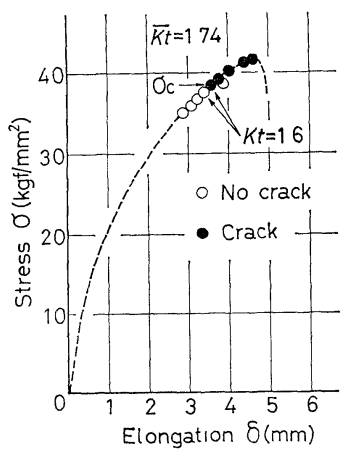

Fig. 8. Results of tensile tests of machined specimens unloaded at various tensile stress levels in molten zinc.

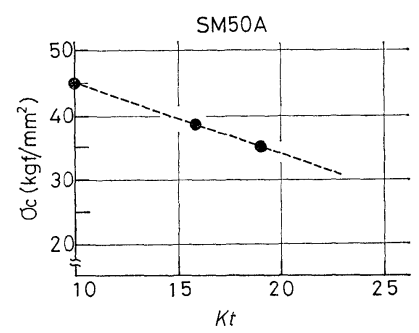

Fig. 9. Relation between stress-concentration factor $\left(K_{t}\right)$ and crack initiating stress $\left(\sigma_{t}\right)$ in molten zinc.
つぎに，溶融亜鉛中でのき裂発生応力 $\sigma_{c}$ を除荷法 により求めた. Fig. 8 と气の結果の 1 例を示す。これ は L-55を用いて溶接した十字すみ肉継手試験片 10 本 について行った試験結果で, $K_{t}=1.6$ のとさ $\sigma_{c}=38.5$ $\mathrm{kgf} / \mathrm{mm}^{2}$ が得られた。 末た，YM-26を用いた十字す み肉溶接継手試験片10本について行った試験結果では,

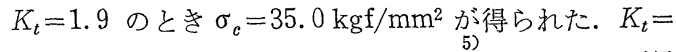
1.0 の平滑材については先に報告したように，ほ注最 大引張応力負荷時にき裂が発生することがわかってお り, 今回の実験結果から $\sigma_{c}=45 \mathrm{kgf} / \mathrm{mm}^{2}$ となる. そ こで, $K_{t}$ と $\sigma_{c}$ との関係を図示すると Fig. 9 のよう になり， $K_{t}=2.0$ 近傍までは $K_{t}$ が増加するにつれて $\sigma_{c}$ は直線的海少している.

\section{$3 \cdot 2$ 鋼管溶接構造試験体の熱応力解析}

Fig. 3 亿示すようにして溶融亜鉛中へ浸せきされつ つある試験体の熱応力分布とその変化を求めるために， 有限要素法を用いた。解析は先に報告したさよらに, 各 要素が亜鉛中へ浸せきされた後の経過時間 $t$ から各要 素の温度を求め, その值をインプットして計算した. 解析は Fig. 3 汇示すよら飞浸せき速度 $V=800 \mathrm{~mm} /$ $\min , 5500 \mathrm{~mm} / \mathrm{min}$ の二と初りにつて，それぞれ の浸せき位置(1)〜(13)おび(1)〜(6)の20ケースについて， 時系列的に行った，液体金属ぜい性化割れは，鋼に溶 融亜鉛が接触した状態で引張応力がはたらいたときに

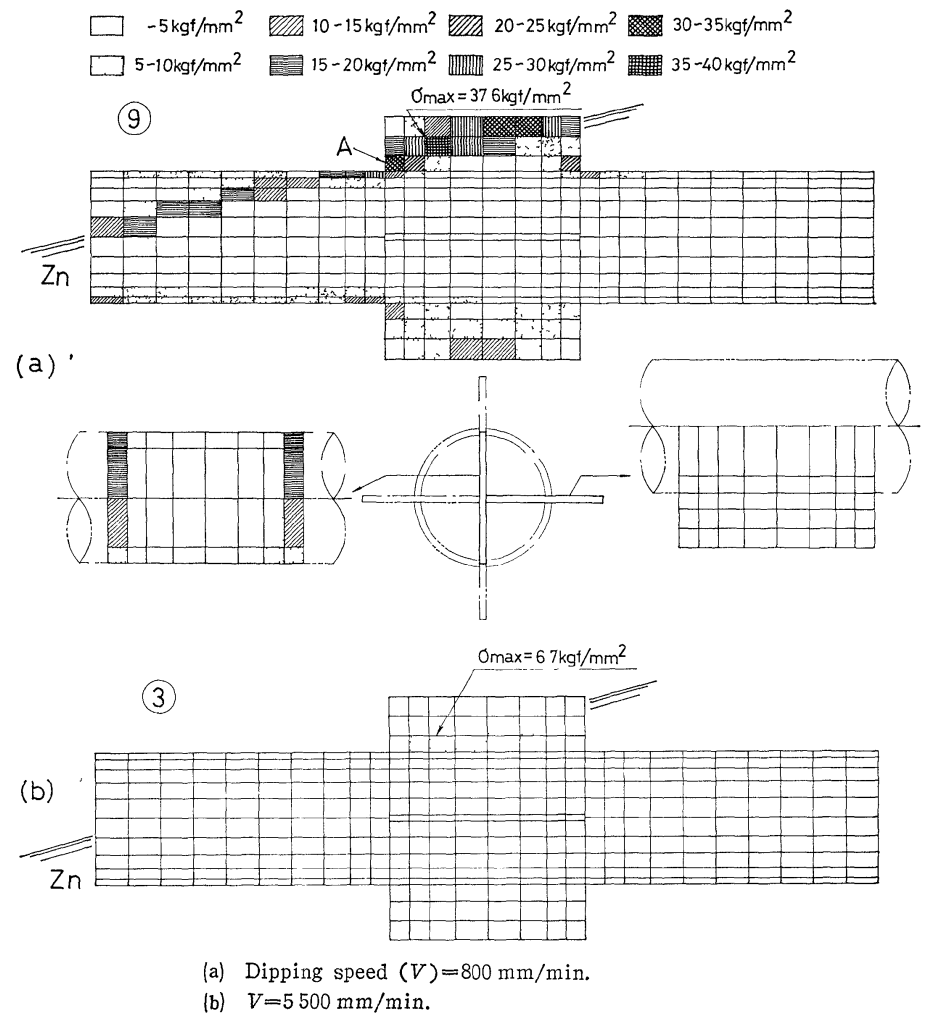

Fig. 10. Tensile thermal stress distribution obtained by the FEM. 
発生するので, 有限要素解析結果から試験体外面の引 張応力分布を求め, Fig. 3 飞抬ける $V=800 \mathrm{~mm} / \mathrm{min}$

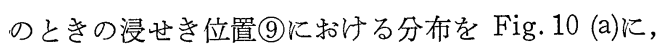
$V=5500 \mathrm{~mm} / \mathrm{min}$ の浸せき位置 (3) 飞拈ける引張応力 分布を Fig. 10 (b)に示した. 解析結果から明らかに， 浸せき速度が速い場合には熱応力が著しく低下するこ とがわかる. $V=800 \mathrm{~mm} / \mathrm{min}$ の場合, 浸せき位置(10 で一部分に最大 $\sigma=42.7 \mathrm{kgf} / \mathrm{mm}^{2}$ の引張応力がはた らき, $V=5500 \mathrm{~mm} / \mathrm{min}$ では, 浸せき位置(3亿捻い て最大引張応力 $\sigma=6.7 \mathrm{kgf} / \mathrm{mm}^{2}$ が発生する.すなわ ち浸せき速度が 6.9 倍になって最大引張応力が $1 / 6.4$ 飞減少する．また，すべての解析結果を調べてみると， 試験体は浸せきされるに従い, あらゆる䇢所に引張応 力が順次に発生することがわかった、鋼管と鋼板との 溶接端部には，応力集中することが考兄られるので， 各浸せき速度に対して, 鋼板隅部（Fig. 10 (a)のA 部) の主応力変化の解析結果を Fig.11 と示した。これは 浸せき速度 $V=800 \mathrm{~mm} / \mathrm{min}$ に和ける Fig. 3 の浸せ き位置(8)，(9)，拉よび(10)対するるのであり，(9)の位 置で最大引張応力 $\sigma=34.9 \mathrm{kgf} / \mathrm{mm}^{2}$ がはたらくこと がわかる.これに対し， $V=5500 \mathrm{~mm} / \mathrm{min}$ の場合は 浸せき位置(4)で最大引張応力 $3.2 \mathrm{kgf} / \mathrm{mm}^{2}$ が発生す るにすぎない。

つぎに，分割要素の大きさの影響を調べるために， Fig. 12 に示すように要素Aの大きさと要素Aにはた らく公称応力 $\sigma$ との関係を有限要素法により解析して 検討を加えた. 要素Aの形状を $l_{2} / l_{1} \fallingdotseq 1.5$ として, 試 験体の浸せき位置をFig. 3 と拈ける $V=800 \mathrm{~mm} / \mathrm{min}$ の場合の (9について計算した。 また試験体の形状・寸 法は Fig. 3 に示すものと同一とした. $l_{1}=70,103.2$, および $150 \mathrm{~mm}$ の場合についての計算結果から $l_{1}$ と
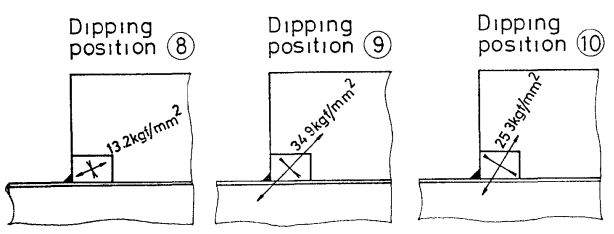

Fig. 11. Thermal stress variation at the corner part of welded steel plate in the case where dipping speed $(V)$ is $800 \mathrm{~mm} / \mathrm{min}$.

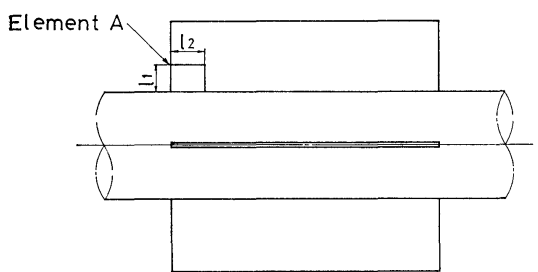

Fig. 12. Shape of the element which is the corner part of welded steel plate.

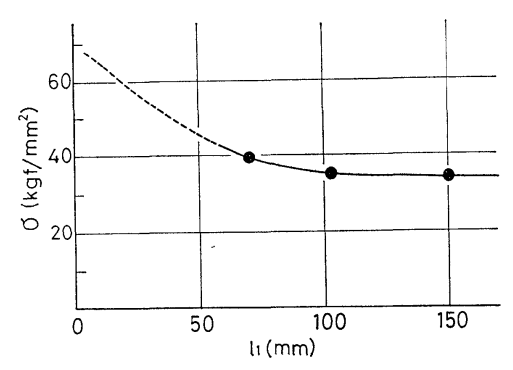

Fig. 13. Relation between nominal tensile stress $(\sigma)$ and length $\left(l_{1}\right)$ of the element located at the corner of the welded steel plate.

$\sigma$ との関係を Fig. 13 と示す. 図から $l_{1}$ が約 $100 \mathrm{~mm}$

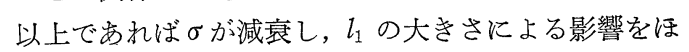
とんど受けないが， $l_{1}$ が $100 \mathrm{~mm}$ よりも小さくなる

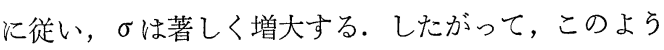
に有限要素解析淿上り公称応力 $\sigma$ 求內て, 裂の発 生を評価する場合には， $l_{1}>100 \mathrm{~mm}$ とすることが必 要である.

\section{$3 \cdot 3$ 鋼管溶接構造試験体の浸せき実験結果}

鋼管溶接構造試験体を溶融亜鉛へ浸せきするとき, 熱応力が大きくなり, 応力集中係数 $K_{t}$ が大きい場合 にはき裂が発生する可能性があるため, 解析の結果大 きい熱灾力が発生する籄所, すなわち, Fig.10 (a)の $\mathrm{A}$ 部に扔ける溶接ビードトウ部の $\rho, \theta$ をンリコンラ バー法により予め測定して，(1)，(2)式により $K_{t}$ を求 めた結果， $K_{t}=2.0$ が得られた．その試験体を Fig. 3 に示す姿勢に保ち, $V=800 \mathrm{~mm} / \mathrm{min}$ の速度で溶融亜 鉛中へ浸せきした，そのときひずみ測定を行った後， 動的みかけのひずみを補正し，熱応力に換算した結果 と熱応力の解析結果とを Fig. 14 と示す. 図から全体 として解析值と実駼值とはかなりよく対応することが わかる，解析值と実験值差があるのは，解析比い ては分割要素の中央部の応力が得られるのに対し, 実 験では分割要素のやや端部に近い位置にひずみゲージ を溶接したためと考觉られる。 そこで, Fig. 11 亿よれ ば，浸せき位置(9に执いて板端の溶接部近傍に 34.9

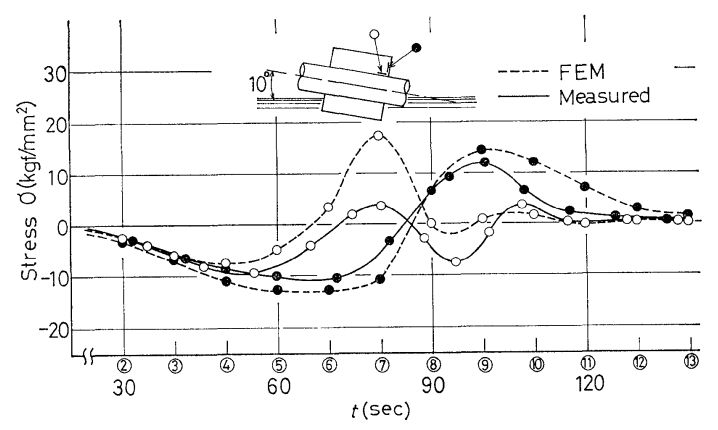

Fig. 14. Results of thermal stress variation obtained by the FEM and experiment. 


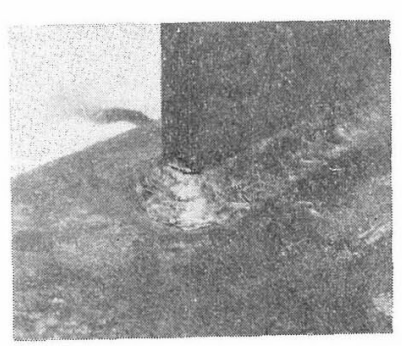

Fig. 15. Photograph of the crack initiated at the toe of the corner part of the plate welded steel pipe.

$\mathrm{kgf} / \mathrm{mm}^{2}$ の引張応力がはたらくことになり，板端の 溶接ビードトウ部で $K_{t}=2.0$ が得られているので， Fig.9 によれば, $V=800 \mathrm{~mm} / \mathrm{min}$ の浸せき速度で板 端溶接部にき裂が発生するものと考元られる。寒験の 結果, Fig. 15 に示すよらに，この溶接ビードトウ部 からき裂が発生した。束た，V=5500 mm/min の湯 合の解析では, 鋼板端部の引張応力は $3.2 \mathrm{kgf} / \mathrm{mm}^{2}$ しか発生せず， $K_{t}=2.0$ としてるき裂発生の可能性が

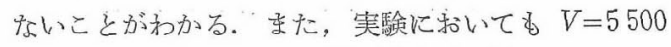
$\mathrm{mm} / \mathrm{min}$ の場合には,き裂の発生がなかった。

$$
4 \text { 結言 }
$$

SM 50 A 鋼を用いて 応力集中部を有する溶接継手 試験片と機械加工による模擬余盛付試験片について, 溶融带鉛中で引張試験を行い, 応力集中係数 $K_{t}$ と応 力・变位曲線扐よびき裂発生応力 $\sigma_{c}$ 之の関係を調べ た.また，鋼管溶接構造物を溶融亚鉛へ浸せきすると きの熱応力変化を有限要素法により解析し, 試験体の 応力集中部の $K_{t}$ との関連に路いてき裂発生の条件を 求め, この実験によりき裂の発生を確認し, 以下の結 論を得た。

（1）溶接継手試験片を溶融亜鉛中で引張ると，ビー ドトウ部からき裂が発生するぶ，発生条件は溶接によ
る金属的な効果よりも形状にこる応力集中の影響が支 配的でめる。

（2）応力集中係数 $K_{t}$ の増加に伴い，引張破断時の 変位が減少し, $K_{t}=2.0$ では $K_{t}=1.0$ の平滑材に対 し，約 $50 \%$ となる。

(3) $K_{t}=1.0 \sim 2.0$ の範囲では, き裂発生応力 $\sigma_{c}$ は $K_{t}$ の増加に伴い, ほぼ直線的に減少し， $K_{t}=2$. 0 で は $K_{t}=1.0$ に詨して $\sigma_{c}$ の值が約 $10 \mathrm{kgf} / \mathrm{mm}^{2}$ 少くな る.

（4）鋼管溶接構造試験体を溶融亚鉛中へ浸せきする ときの熱応力変化を有限要素法により求め， $K_{t}$ との 関係に执いて理論的に求めたき裂発生条件は, 実験結 果とよく一致する.

（5）浸せき速度を速くすると熱応力が減少し，き裂 発生防止に有效である.

終りに, 本研究のためにご指導を賜った東京工業大 学の中澤一教授および応力集中部の測定法についてご 助言を賜った金属材料技術研究所の太田昭彦氏に深県 なる謝意を表します。.

(昭和56年 5 月19日 日本材料学会第30期学術講演会にて講演)

\section{参 考 文 献}

1) 稻垣博巳，ぶれいず，49, 27 (1980).

2）松下幸正，七沢和男，大型悪鉛めっき鋼構造物に関する 調查報告書, 65 (1979), 亜鉛》っき鋼構造物研究会

3) 菊池昌利, 家沢 徹, 材料, 30, 187 (1981).

4) 菊池昌利, 家沢 徹, 材料, 30, 562 (1981).

5) Kikuchi, M., Proc. 23rd Jap. Cong. Mat. Res., 143 (1980).

6) 金井健二, 非破猿検査, 29, 11 (1980).

7) 菊池昌利, 非破壞検査, 29, 544 (1980).

8) 西田正孝, “応力集中”, p. 632 (1969) 森北出版 